\title{
PKM MENINGKATKAN KESADARAN MENJAGA KESEHATAN DAN KEBERSIHAN LINGKUNGAN MASYARAKAT PADA MASA PANDEMI
}

\author{
Angga Rezaldy Kristyawan ${ }^{1}$, Putri Indah Novitalia ${ }^{2}$, Yosua Anggun Putra ${ }^{3}$, Heristama \\ Anugerah Putra ${ }^{4}$ \\ 1,2,3,4 Universitas Katolik Darma Cendikia \\ Email : anggarezaldy19@gmail.com
}

\begin{abstract}
Abstrak
Tahap awal yang dilakukan peserta Pengabdian Masyarakat (Abdimas) seperti biasa adalah melakukan analisis sosial (Ansos). Ansos kali ini terasa cukup mudah karena pada Abdimas sebelumnya sudah dilakukan Ansos bersama dengan tim anggota KKN dan Pengabdian kepada Masyarakat (LPPM) Universitas Katolik Darma Cendika (UKDC) Tahun 2021 sebagaimana dilaporkan oleh KKN 2020). Setelah mendapatkan ijin baik dari pihak RT 01 PERUM KALIJUDAN INDAH dan LPPM UKDC maka tim KKN kali ini mengawali dengan Rapat tim KKN dilakukan secara online pada 08 april 2021 . Dari sejumlah 83 Kepala Keluarga (KK) di RT 01 tim KKN diarahkan agar melakukan penyuluhan tentang kesehatan dan kebersihan lebih rinci kepada 11 (sebelas) KK saja setelah terlebih dahulu memberikan penjelasan dan pemyuluhan dan masing-masing $\mathrm{KK}$ tersebut akan diarahkan untuk mengisi kuisoner supaya Ansos yang dilakukan bisa berjalan dengan mudah dari bantuan Ansos tersebut.
\end{abstract}

Kata kunci : Menjaga Lingkungan, Kesehatan, dan Kebersihan

\section{Abstract}

The initial stage performed by community service participants, as usual, is to conduct social analysis. This time feels relatively easy because previously, it has been done together with a team of members and Community Service Darma Cendika Catholic University (UKDC) year 2021, as reported. After obtaining good permission from RT 01 PERUM KALIJUDAN INDAH and LPPM UKDC, the team started with a team meeting conducted online on April 08, 2021. From some 83 Family Heads in RT 01 team directed to conduct counseling about health and hygiene in more detail to 11 (eleven) families only after first giving explanations and recitations and each of them will be directed to fill out the questionnaire so that Ansos conducted can run efficiently from the help.

Keywords: Maintaining the Environment, Health, Healthy 


\section{PENDAHULUAN}

KKN adalah kegiatan yang dilaksanakan setiap tahun di semua universitas tapi untuk kali ini laporan dan KKN dilaksanakan oleh UNIVERSITAS DARMACENDIKA dan KKN dilakukan diberbagai tempat dan salah satu tempat dilaksanakan di Perumahan Villa Kalijudan Indah, dengan melakukan berbagai kegiatan seperti melakukan survei dan melakukan analisis social dan juga akan melakukan penyuluhan diberbagai sumber masyarakat serta serta melakukan tindakan kebersihan lingkungan.

Pada dasarnya Kuliah Kerja Nyata $(\mathrm{KKN})$ merupakan bentuk pengabdian nyata mahasiswa kepada masyarakat. Setelah mendapatkan materi perkuliahan yang senantiasanya dapat berguna didalam lingkungan masyarakat itu sendiri. Dalam kegiatan pengabdiannya pada masyarakat, mahasiswa memberikan pengalaman ilmu pengetahuan, teknologi, seni, dan agama untuk memberikan pengarahan agar dapat memecahkan masalah dan menanggulanginya secara tepat. Selain itu, pembenahan sarana dan prasarana merupakan kegiatan yang dilakukan serta menjadi program kerja bagi mahasiswa. Dengan kata lain, melalui $\mathrm{KKN}$ ini, mahasiswa membantu pembangunan dalam masyarakat/ pemberdayaan masyarakat .

Gambar situasi lokasi di Villa Kalijudan Indah Surabaya warga di lingkungan ini besar biasanya menjalankan kesibukan dengan bekerja jadi situasi jalan di lingkungan Villa Kalijudan sangat sepi tetapi banyak sampah yang masih menggunung dan menumpuk di berbagai tempat atau di sebagian besar tempat di villa Kalijudan indah, berdasarkan hasil analisis kami banyak sekali warga yang ada di Villa Kalijudan Indah belum bisa untuk mematuhi protokol kesehatan dan juga memperdulikan kesehatan dan kebersihan lingkungan, dan juga banyak sekali rumah-rumah warga yang masih kotor karena daun atau kotoran sampah yang menggunung, banyak sekali juga kotoran daun

Berdasarkan hasil analisa dan wawancara kami dengan bapak RT yang ada di Villa Kalijudan memang banyak sebagian warga besar perumahan Villa Kalijudan cuek dengan keadaan dan kondisi yang ada di Villa Kalijudan Indah seperti kebersihan dan kesehatan warga yang ada di villa Kalijudan indah karena mereka merasa mereka memiliki kesibukan tersendiri dengan bekerja, harapan warga kedepannya dan sebagian besar warga kedepannya Villa Kalijudan Indah bisa bersih dari sampah dan kotoran kotoran lain serta harapan besar pengurus 
Villa Kalijudan Indah warga Villa Kalijudan Indah bisa dan mau untuk diajak kerjasama supaya Villa Kalijudan Indah bisa terlihat bersih dari sampah.

Warga juga memberikan informasi bahwasanya kebersihan di Villa Kalijudan Indah itu masih kurang karena warga sering cuek dan tidak peduli dengan lingkungan dia sendiri atau lingkungan sekitar di Villa Kalijudan Indah.

Tujuan dari program pengabdian masyarakat di kelompok 23:

1. Untuk memberikan edukasi kepada masyarakat Villa Kalijudan Indah tentang kebersihan dan kesehatan yang masih minim mereka dapatkan.

2. Untuk memberikan sosialisasi dan memberikan arahan kepada masyarakat Villa Kalijudan Indah tentang kebersihan.

Mahasiswa Universitas Katolik Darma Cendika ( UKDC ) pada hari Minggu tanggal 18 April 2021 kami melakukan kegiatan peduli lingkungan dengan menjaga kesehatan dan kebersihan di Perumahan Villa Kalijudan Indah blok C-19, Pacar Kembang, Surabaya. Kegiatan ini dalam rangka Program Pengabdian kepada masyarakat, mahasiswa UKDC memilih tempat di daerah tersebut termasuk dalam kawasan yang kurang dalam menjaga kebersihan, apalagi di masa pandemi covid-19 saat ini.

Kondisi yang dihadapi warga Villa Kalijudan Indah dapat dikatakan bervariasi ada yang memperhatikan kebersihan kebersihan dan ada juga tidak peduli pada lingkungan sekitar dari dampak tersebut mengakibatkan banyaknya sampah berserakan dan kurangnya tenaga kebersihan. Adanya kelompok KKN dari Universitas Katolik Darma Cendika sangat berdampak besar bagi Masyarakat Villa Kalijudan karena bisa membantu warga untuk peduli terhadap lingkungannya tersebut.

Dari situ warga menyadari kusus dimasa pandemi Covid - 19 ini sangatlah penting menjaga kebersihan, supaya bisa memutuskan mata rantai penyebaran Covid-19 dan warga juga dibiasakan untuk menggunakan masker, mencuci tangan setelah keluar dari rumah, menggunakan handsatizer agar membunuh virus dan tidak menyebabkan penularan kepada anggota keluarga yang lain.

Pelaksanaan Program Pengabdian masyarakat ini juga membantu Ketua RT 01 dan masyarakat itu sendiri mewujudkan program kesehatan dan Kebersihan dimasa pandemi covid - 19. Hal ini nantinya juga akan tetap diawasai dan dievaluasi oleh Monitoring dan pengawas di lingkungan RT tersebut. "Saya selaku RT dan pengawas lingkungan Villa kalijudan Indah 
mengucapkan terimakasih banyak, karena teman-teman mahasiswa universitas Katolik Darma Cendika ( UKDC ), bisa memberikan pelayanan dan sosialisasi kepada warga Villa Kalijudan Indah. Karena saat ini dimasa pandemi C-19 dampaknya begitu terasa bagi warga Villa Kalijudan. Sekali lagi kami mewakilkan mengucapkan terimakasih banyak," kata Ketua RT 01 Villa Kalijudan Indah, Surabaya.

\section{METODE}

Pelaksanaan program pengabdian masyarakat kelompok 23 ini dimulai sejak bulan Februari 2021 dan telah selesai pada bulan Mei 2021 tahapan pelaksanaan kegiatan.Tahapan kegiatan dilakukan oleh kelompok 23 dalam program kegiatan pengabdian masyarakat di Villa Kalijudan Indah adalah sebagai berikut;

\section{A. Pembekalan dan penentuan tujuan lokasi program pengabdian masyarakat.}

Lokasi program pengabdian masyarakat kelompok 23 dilakukan di Villa Kalijudan Indah kota Surabaya berikut gambar daerah lokasi yang diambil dari Google Map.

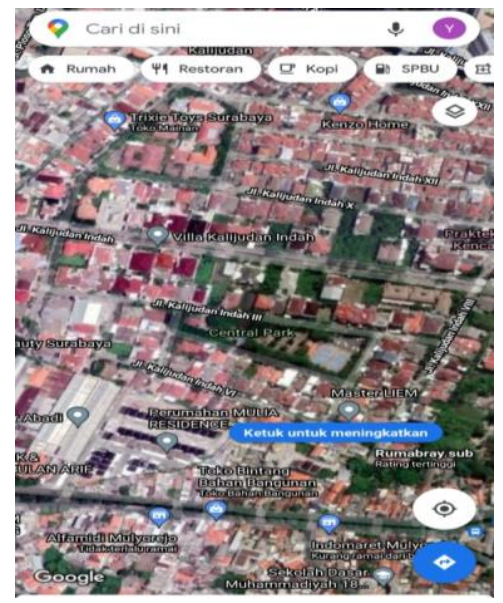

\section{B. Melakukan survei lokasi kegiatan program pengabdian masyarakat kelompok23}

Survei lokasi dan kunjungan dilakukan oleh perwakilan anggota kelompok 23 kunjungan ini bertujuan untuk bersilahturahmi dengan perwakilan warga serta melakukan wawancara dan mencari informasi tentang situasi dan kondisi di lingkungan sekitar pelaksanaan program pengabdian masyarakat jadwal pelaksanaan survei ini serentak dilakukan di dua lokasi mengingat hanya perwakilan kelompok yang melakukan kunjungan maka waktu pelaksanaan bisa bersama-sama. Hal ini dilakukan dalam rangka mematuhi protokol kesehatan, yaitu menghindari kerumunan pelaksanaan pembersihan lokasi juga menggunakan protokol kesehatan lengkap yaitu memakai masker tidak berjabat tangan serta menjaga jarak. 
C. Melakukan analisa sosial di Villa Kalijudan Indah Surabaya analisis sosial dilakukan di RT 01 Perumahan Villa Kalijudan Indah, analisa sosial dilakukan agar kelompok 23 mengetahui tentang keadaan geografis, keadaan lingkungan, kondisi sosial dan ekonomi kegiatan masyarakat serta permasalahan yang ada dihadapi oleh warga Villa Kalijudan Indah RT 01 Surabaya. Sambil melakukan koordinasi lebih lanjut untuk perencanaan program kerja yang akan dilaksanakan.

\section{Tahap pelaksanaan program kerja pengabdian masyarakat.}

Tahap pertama yaitu dengan melakukan kunjungan ke rumah warga dan mendata serta membantu dalam pembersihan lingkungan Villa Kalijudan Indah tahap kedua menghitung dan mendata sebagian warga, tahap ketika melakukan wawancara serta penyuluhan terhadap warga Villa Kalijudan Indah tentang kebersihan lingkungan.

\section{E. Proses realisasi program kerja pengabdian masyarakat kelompok 23}

Realisasi kegiatan program pengabdian masyarakat berupa pembersihan lingkungan dan juga pemberian edukasi tentang kebersihan dan kesehatan lingkungan yang dilakukan oleh kelompok 23 dengan datang ke beberapa KK di Perumahan Villa Kalijudan Indah yang menurut RT atau pengurus Villa Kalijudan Indah yang masih belum mematuhi atau belum mengetahui tentang kebersihan dan kesehatan di lingkungan ini, kemudian kami juga mendata $11 \mathrm{KK}$ yang kami berikan sosialisasi tersebut supaya pengurus bisa mengevaluasi keadaan sekitar rumah beberapa KK tersebut.

\section{HASIL DAN PEMBAHASAN}

Program kerja pengabdian masyarakat kelompok 23 bertujuan untuk membantu warga mengelola dan membersihkan sampah yang ada di daerah Villa Kalijudan Indah supaya lingkungan Kalijudan Indah bisa terlihat bersih dan terhindar dari kotoran serta sakit penyakit terutama saat Pandemi Covid-19 saat ini, melalui program pengabdian masyarakat ini kelompok 23 memberikan edukasi dan informasi yang bermanfaat bagi warga villa Kalijudan indah supaya mereka bisa hidup bersih serta bisa membersihkan lingkungan sekitar mereka supaya terhindar dari sakit penyakit. Melalui metode survei dan juga memberikan edukasi kami harapkan warga Villa Kalijudan Indah bisa lebih lagi memperhatikan kebersihan dan kesehatan mereka terutama di lingkungan rumah mereka. Hal ini disebabkan karena adanya ketidaknyamanan dari beberapa warga tentang kebersihan yang kurang di beberapa KK yang ada ada di Villa Kalijudan Indah. 
Program kerja pengabdian masyarakat kelompok 23 bertujuan untuk membantu beberapa KK yang ada di Villa Kalijudan Indah supaya mereka bisa mengerti dan paham tentang kesehatan dan kebersihan di lingkungan rumah mereka dan salah satu usaha kami adalah dengan bergerak membersihkan beberapa tempat di rumah warga yang terlihat kotor.

\section{GAMBAR 1;MEMBERSIHKAN HALAMAN RUMAH}

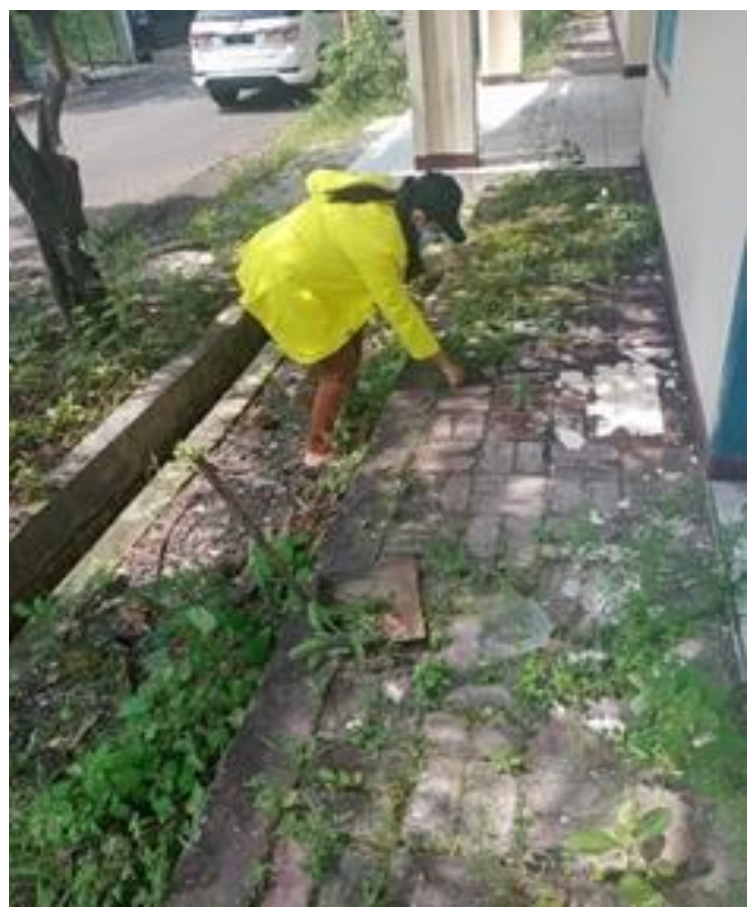

GAMBAR 2 PEMBERSIHAN LINGKUNGAN JALAN

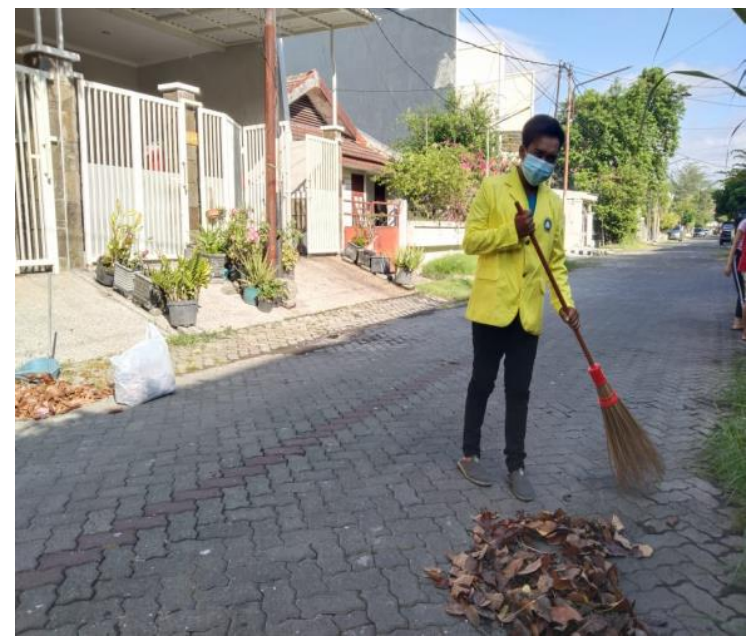




\section{GAMBAR 3 PEMBERSIHAN LINGKUNGAN JALAN}

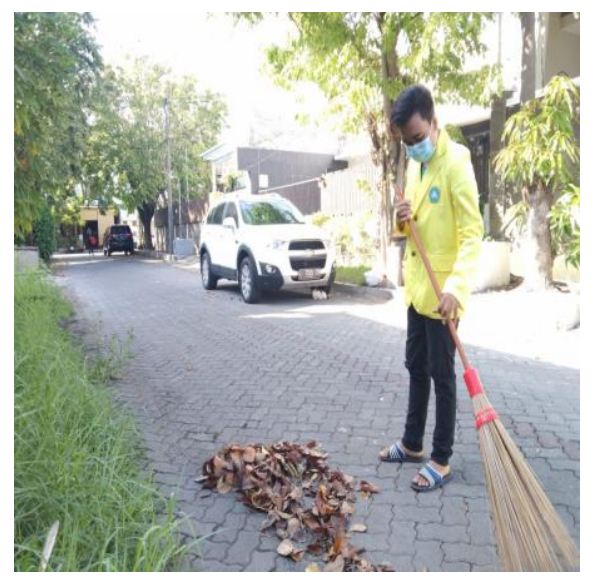

Melalui program kerja pengabdian masyarakat kelompok 23 berupa pembersihan lingkungan dan pembelian alat-alat kebersihan yang diberikan untuk membantu membersihkan jalan dan sekitar rumah di beberapa KK di Villa Kalijudan Indah, perubahan yang bermanfaat bagi warga perumahan Villa Kalijudan Indah Surabaya yaitu;

1. Mengembalikan alat kebersihan seperti sapu alat pel dan alat kebersihan lainnya.

2. Memberikan edukasi dan pengertian tentang kesehatan dan kebersihan di lingkungan Villa Kalijudan Indah.

\section{KESIMPULAN}

Berdasarkan hasil kegiatan pengabdian masyarakat kelompok 23 yang telah dilaksanakan ini dapat diambil kesimpulan sebagai berikut;

1. Proses edukasi dan pembersihan lingkungan di Villa Kalijudan Indah mulai dari awal hingga tahap akhir dibuktikan dengan respon pengurus dan respon warga di Villa Kalijudan Indah yang sangat baik dan mereka juga mengikuti apa yang diarahkan.

2. Telah terealisasikan pembersihan lingkungan yang dilaksanakan oleh pengabdian masyarakat kelompok 23 di Villa Kalijudan Indah Surabaya 


\section{DAFTAR PUSTAKA}

AR Chaerudin, Bambang Setiadi, \& Ahmad Munawir. (2020). PEMBERDAYAAN EKONOMI MASYARAKAT BERBASIS EKONOMI KREATIF DI DESA CITAMAN KECAMATAN CIOMAS KABUPATEN SERANG BANTEN. Jurnal Abdimas Bina Bangsa, 1(1), 26-37. doi:10.46306/jabb.v1i1.9

Arsyad dan Bongkareng. Upaya-upaya Penyehatan Rumah (Rumah Sehat). Heru Subaris Kasjono (ed.). Yogyakarta. Gosyen Publishing.

Arumsari, Sutingningsi dan Hestiningsih. 2012. Jurnal Kesehatan Masyarakat Volume 1, Nomor 2, halaman 514 - 524. Analisis Faktor Lingkungan Abiotik Yang Mempengaruhi Keberadaan Leptospirosis pada Tikus di Kelurahan Sambiroto, Tembalang, Semarang. Azwar, A. (1996). Pengantar Ilmu Kesehatan Lingkungan . Jakarta : Mutiara Sumber Widya. Depkes RI. 1991. Petunjuk Teknis Sarana Kesehatan Lingkungan. Departemen Kesehatan Republik Indonesia : Jakarta

Kamaliah, K. (2018). Tingkat Partisipasi Ibu Rumah Tangga tentang Sampah terhadap Pemeliharan Kebersihan Lingkungan. Media Ilmiah Teknik Lingkungan, 3(2), 12-15. doi:10.33084/mitl.v3i2.644

Manurung, E. M., Djelantik, S., \& Indraswari, I. (2019). Film Sebagai Media Edukasi: Peningkatan Kesadaran Masyarakat Tentang Kebersihan Lingkungan. Prosiding Konferensi Nasional Pengabdian Kepada Masyarakat Dan Corporate Social Responsibility (PKM-CSR), 2, 131-137. doi:10.37695/pkmcsr.v2i0.552

Nora Pitri Nainggolan, \& Intan Utna Sari. (2020). PEMBINAAN DAN PENERAPAN STRATEGI PEMASARAN MELALUI MEDIA SOSIAL PADA HOME INDUSTRI MASYARAKAT TANJUNG GUNDAP. Jurnal Abdimas Bina Bangsa, 1(2), 267-275. doi:10.46306/jabb.v1i2.31

Pujiono, M., Agustono, B., \& Adha, T. K. R. (2018). Community Service on the Improvement of Clean Environement Based on Waste Bank in the Sub-District of Bahari Belawan (PKM Peningkatan Kebersihan Lingkungan Berbasis Bank Sampah di Kelurahan Bahari Belawan). LOGISTA - Jurnal Ilmiah Pengabdian Kepada Masyarakat, 2(2), 9. doi:10.25077/logista.2.2.9-16.2018

Safitri, W., \& Degita Azis, A. (2020). MEMBANGUN SISTEM FLEXIBLE BUDGETING DAN PENDAMPINGAN KEBERSIHAN MUSHOLA NURUL HUDA SAAT 
PANDEMI COVID19. PKM-P, 4(2), 198. doi:10.32832/pkm-p.v4i2.746

Sari, R. P. (2019). Wawasan Kebersihan Lingkungan \& Keberagamaan; Praktik Kebersihan Lingkungan pada Civitas Akademika UIN Imam Bonjol Padang. Indonesian Journal of Religion and Society, 1(1), 80-92. doi:10.36256/ijrs.v1i1.8

Sarlotha Yulliana Purimahua, Junus Kwelju, \& Maya Laisila. (2020). Usaha Mikro dan Cara Mengatur Usaha Masyarakat di Negeri Hatu, Maluku Tengah. Jurnal Abdimas Bina Bangsa, 1(1), 107-118. doi:10.46306/jabb.v1i1.16

Vivien Novarina A. Kasim, \& Nirwanto K. Rahim. (2020). PEMBERDAYAAN LINGKUNGAN PADA MASYARAKAT SADAR GIZI UNTUK KETAHANAN PANGAN DESA. Jurnal Abdimas Bina Bangsa, 1(2), 257-266. doi:10.46306/jabb.v1i2.46 